\title{
Induction of thymic stromal lymphopoietin expression in 16-HBE human bronchial epithelial cells by 25-hydroxyvitamin $D_{3}$ and 1,25-dihydroxyvitamin $D_{3}$
}

\author{
DAN ZHANG $^{1 *}$, CHENGHUA PENG $^{2 *}$, HAIJIN ZHAO $^{1 *}$, YANG XIA $^{1}$, DANDAN ZHANG $^{1}$, \\ HANGMING DONG $^{1}$, JIAFU SONG ${ }^{1}$, LIQIN ZHOU ${ }^{1}$, SHAOXI CAI ${ }^{1}$ and FEI ZOU ${ }^{2}$ \\ ${ }^{1}$ Department of Respiratory and Critical Care Medicine, Chronic Airways Diseases Laboratory, Nanfang Hospital, \\ ${ }^{2}$ School of Public Health and Tropical Medicine, Southern Medical University, Guangzhou, Guangdong 510515, P.R. China
}

Received February 8, 2013; Accepted April 2, 2013

DOI: $10.3892 /$ ijmm.2013.1353

\begin{abstract}
Vitamin D exerts profound effects on airway epithelial cells. Thymic stromal lymphopoietin (TSLP) derived from airway epithelial cells plays a role in the innate and antigen-specific adaptive immune responses. However, the effect of vitamin D on TSLP expression in airway epithelial cells is unclear. In this study, 16-HBE human bronchial epithelial (HBE) cells were cultured with various concentrations of 25-hydroxyvitamin $\mathrm{D}_{3}\left(25 \mathrm{D}_{3}\right)$ and 1,25-dihydroxyvitamin $\mathrm{D}_{3}$ $\left(1,25 \mathrm{D}_{3}\right)$. The expression of TSLP in the 16-HBE human bronchial epithelial cell line was analyzed by PCR and enzymelinked immunosorbent assay (ELISA). We found that the 16-HBE cells converted inactive $25 \mathrm{D}_{3}$ to active $1,25 \mathrm{D}_{3}$ and that TSLP mRNA and protein expression levels were significantly increased, peaking at 2 or $12 \mathrm{~h}$ in the cells exposed to $500 \mathrm{nM}_{25} \mathrm{D}_{3}$ and $50 \mathrm{nM} 1,25 \mathrm{D}_{3}$ respectively. Since vitamin $\mathrm{D}_{3}$ upregulated protein 1 (VDUP1) plays a multifunctional role in a variety of cellular responses, we hypothesized that VDUP1 is involved in the induction of TSLP production by $25 \mathrm{D}_{3}$. The
\end{abstract}

Correspondence to: Professor Shaoxi Cai, Department of Respiratory and Critical Care Medicine, Chronic Airways Diseases Laboratory, Nanfang Hospital, Southern Medical University, No. 1838 Guang Zhou Da Dao Bei, Guangzhou, Guangdong 510515, P.R. China E-mail: caishaox@fimmu.com

Professor Fei Zou, School of Public Health and Tropical Medicine, Southern Medical University, No. 1838 Guang Zhou Da Dao Bei, Guangzhou, Guangdong 510515, P.R. China

E-mail: zfei@fimmu.com

*Contributed equally

Abbreviations: ELISA, enzyme-linked immunosorbent assay; $1,25 \mathrm{D}_{3}$, 1,25-dihydroxyvitamin $\mathrm{D}_{3} ; 25 \mathrm{D}_{3}, 25$-hydroxyvitamin $\mathrm{D}_{3}$; HBE cells, human bronchial epithelial cells; siRNA, small interfering RNA; TSLP, thymic stromal lymphopoietin; VDUP1, vitamin $\mathrm{D}_{3}$ upregulated protein 1

Key words: asthma, human bronchial epithelial cells, thymic stromal lymphopoietin, vitamin $\mathrm{D}$, vitamin $\mathrm{D}_{3}$ upregulated protein 1 results showed that the mRNA and protein levels of VDUP1 were significantly upregulated by vitamin D. Furthermore, the silencing of VDUP1 by small interfering RNA (siRNA) significantly inhibited the $25 \mathrm{D}_{3}$ - and 1,25 $\mathrm{D}_{3}$-mediated induction of TSLP expression. To characterize the metabolic properties of vitamin D in airway epithelial biology, we used the chemical inhibitor of $1 \alpha$-hydroxylase, itraconazole. The results revealed that itraconazole $\left(10^{-6} \mathrm{M}\right)$ reduced the $25 \mathrm{D}_{3}$ - but not the $1,25 \mathrm{D}_{3}$-induced TSLP expression in 16-HBE cells. Based on these data, it can be concluded that vitamin D increases TSLP expression in 16-HBE cells through the VDUP1 pathway, which suggests a novel mechanism by which vitamin $\mathrm{D}$ alters immune function in the lungs.

\section{Introduction}

Emerging evidence indicates that vitamin D insufficiency is associated with several lung diseases, including asthma and chronic obstructive pulmonary disease (COPD), which may be associated with impaired pulmonary function, and the increased incidence of inflammation and infection $(1,2)$. The exact underlying mechanisms are unknown; however, vitamin D appears to affect the function of inflammatory and structural cells, including lymphocytes, dendritic cells, monocytes and epithelial cells $(1,3,4)$. 1 $\alpha$-hydroxylase is responsible for the final and ratelimiting step in the synthesis of active 1,25-dihydroxyvitamin $\mathrm{D}_{3}$ $\left(1,25 \mathrm{D}_{3}\right)$ from the circulating or storage form, 25-hydroxyvitamin $\mathrm{D}_{3}\left(25 \mathrm{D}_{3}\right)(5)$. In 2008, Hansdottir et al reported that airway epithelial cells express $1 \alpha$-hydroxylase and are able to convert vitamin D from an inactive form into an active one, and that vitamin D affects the expression of vitamin D-driven genes that play a major role in host defense (4). The expression of $1 \alpha$-hydroxylase in airway epithelial cells suggests a broader role of vitamin $\mathrm{D}$ in respiratory diseases.

Airway epithelial cells are not only physical barriers to invaders, but also produce cytokines, such as thymic stromal lymphopoietin (TSLP) in response to allergens (6). The overexpression of the TSLP gene in airway epithelial cells has been shown to lead to asthma and TSLP has been suggested to play an important role in the initiation and maintenance of the allergic immune response $(6,7)$. TSLP expression has been shown to 
be induced by $1,25 \mathrm{D}_{3}$ in SCC25 human epithelial tumor cells (derived from a tongue squamous cell carcinoma) (8). It has also been demonstrated that the topical application of $1,25 \mathrm{D}_{3}$ leads to the induction of TSLP expression in mouse epidermal keratinocytes (9). However, whether vitamin D affects the expression of TSLP in human bronchial epithelial (HBE) cells remains unresolved.

Vitamin $\mathrm{D}_{3}$ upregulated protein 1 (VDUP1) is an endogenous inhibitor of thioredoxin. VDUP1 was originally identified as a differentially expressed gene in $1,25 \mathrm{D}_{3}$-treated HL-60 leukemia cells (10). It is cytoplasmically located and has been shown to play a multifunctional role in a variety of cellular responses $(11,12)$. Recently, VDUP1 has been shown to play a role in vascular endothelial growth factor (VEGF)- and interleukin-1 $\beta$-mediated signal transduction pathways (13-15). However, little is known about the expression of VDUP1 in bronchial epithelial cells and its involvement in the activation of these cells.

In this study, to determine whether vitamin D enhances the expression of TSLP in airway epithelial cells and whether VDUP1 is involved in this process, 16-HBE cells were used. This SV40 large T antigen-transformed bronchial epithelial cell line is widely used for the investigation of the functional properties of bronchial epithelial cells $(16,17)$. The results from this study demonstrate that TSLP expression can be manipulated by both inactive and active vitamin $\mathrm{D}$ via the VDUP1 pathway, therefore suggesting a novel mechanism by which vitamin $\mathrm{D}$ regulates immune function in the lungs.

\section{Materials and methods}

Cell culture, treatment and transfection. 16-HBE bronchial epithelial cells (Shanghai Fuxiang Biological Technology Co., Ltd., Shanghai, China) were cultured in MEM growth medium (Ginuo Biopharm Technology Co., Shanghai, China) supplemented with $10 \%$ fetal calf serum (Invitrogen Life Technologies, Carlsbad, CA, USA) and maintained at $37^{\circ} \mathrm{C}$ in a humidified incubator in the presence of $5 \% \mathrm{CO}_{2}$. Cells were cultured for at least 2 days (70-80\% confluence) prior to stimulation with $25 \mathrm{D}_{3}$ and 1,25 $\mathrm{D}_{3}$ (Sigma, St. Louis, MO, USA) for $6 \mathrm{~h}$ with or without pre-treatment with 1,000 nM itraconazole (Sigma) for $2 \mathrm{~h}$ (4).

The sequence of the VDUP1-targeting small interfering RNA (siRNA) was as follows: siRNA1 sense, 5'-GUCAGAGG CAAUCAUAUUATT-3' and antisense, 5'-UAAUAUGAUUG CCUCUGACTG-3'; siRNA2 sense, 5'-CUGUGAAGGUGA UGAUAUUTT-3' and antisense, 5'-AAUCUCAUCACCUUC ACAGTT-3'; siRNA3 sense, 5'-GAAACAAAUAUGAGUA CAATT-3' and antisense, 5'-UUGUACUCAUAUUUGUUU CCA-3'; and negative control (NC) sense, 5'-UUCUCCGAAC GUGUCACGUTT-3' and antisense, 5'-ACGUGACACGUU CGGAGAATT-3'. All siRNAs were purchased from Shanghai GenePharma Co., Ltd., Shanghai, China. The 16-HBE cells were seeded at a density of $1.2 \times 10^{5}$ cells/well in 12-well culture plates and cultured for 2 days. Cells that were $40-60 \%$ confluent, were transfected with $5 \mathrm{nM}$ VDUP1-specific siRNA or control siRNA using the HiPerFect transfection reagent (Qiagen, Hilden, Germany) according to the manufacturer's instructions. The viability of the cells was determined by MTT assay. The transfected cells were cultured for an additional $48 \mathrm{~h}$ and then

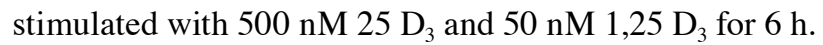

Quantitative determination of 1,25 $D_{3} .1,25 \mathrm{D}_{3}$ was quantified using an enzyme immunoassay kit for $1,25 \mathrm{D}_{3}$ (Yanjie Biotechnology, Shanghai, China) according to the manufacturer's instructions.

RNA isolation and real-time polymerase chain reaction (PCR). Gene expression was analyzed by real-time RT-PCR using SYBR ${ }^{\circledR}$ Premix Ex Taq ${ }^{\mathrm{TM}}$ (Takara, Dalian, China) and the Mx3005p real-time qPCR system (Stratagene, Santa Clara, CA, USA). Total RNA was extracted with RNAisoPLUS (Takara) following the manufacturer's instructions and cDNA was synthesized from $500 \mathrm{ng}$ of RNA using the PrimeScript ${ }^{\mathrm{TM}}$ RT kit. The qRT-PCR reaction mixture contained $1 X$ SYBR Premix Ex Taq, $200 \mathrm{nM}$ forward and reverse primers and $2 \mu \mathrm{l}$ cDNA in a final volume of $25 \mu \mathrm{l}$. The primers (Invitrogen, Shanghai, China) used were: human TSLP (forward, 5'-GCCC AGGCTATTCGGAAAC-3' and reverse, 5'-GAAGCGACG CCACAATCC-3'), VDUP1 (forward, 5'-ACTCGTGTCAAAG CCGTTAGGA-3' and reverse, 5'-AGCTCAAAGCCGAACTT GTACTCA-3') and $\beta$-actin (forward, 5'-GTGGACATCCGC AAAGAC-3' and reverse, 5'-GAAAGGGTGTAACGC AACT-3'). The PCR cycling conditions were as follows: $95^{\circ} \mathrm{C}$ for $15 \mathrm{sec}, 58^{\circ} \mathrm{C}$ for $15 \mathrm{sec}$ and $72^{\circ} \mathrm{C}$ for $15 \mathrm{sec}$ for 40 cycles. The melting curve was made by increasing the temperature from 65 to $95^{\circ} \mathrm{C}$ at a ramp rate of $2 \%$ for $20 \mathrm{~min}$. The qRT-PCR samples were evaluated using a single predominant peak as a quality control. The cycle threshold $(\mathrm{Ct})$ values were used to calculate the relative expression levels of the messenger RNA (mRNA). The expression levels of all genes were normalized to the expression of a reference gene ( $\beta$-actin).

Western blot analysis. The cells were washed 3 times with phosphate-buffered saline (PBS) and disrupted in ice-cold lysis buffer (20 mM Tris, $20 \mathrm{mM} \beta$-glycerophosphate, $150 \mathrm{mM} \mathrm{NaCl}$, $3 \mathrm{mM}$ EDTA, 3 mM EGTA, $1 \mathrm{mM} \mathrm{Na} \mathrm{VO}_{4}, 0.5 \%$ Nonidet $\mathrm{P}-40$ and $1 \mathrm{mM}$ dithiothreitol). The protein concentration of the lysates was determined using the Bradford protein assay (Nanjing KeyGen Biotech. Co., Ltd., Nanjing, China). Protein (40 $\mu \mathrm{g}$ /lane) was separated on a $10 \%$ SDS-polyacrylamide gel and transferred onto a PVDF membrane (Millipore, Billerica, MA, USA). The membrane was blocked with 5\% skim milk in Tris-buffered saline with Tween-20 (TBST) (50 mM Tris-HCl, $\mathrm{pH} 7.5,150 \mathrm{mM} \mathrm{NaCl}$ and $0.05 \%$ Tween-20) for $1 \mathrm{~h}$ at room temperature and then incubated overnight with rabbit antihuman VDUP1 polyclonal antibody (Santa Cruz Biotechnology, Inc., Santa Cruz, CA, USA) 1:600 at $4^{\circ} \mathrm{C}$. The membrane was washed with TBST (3x15-min washes) and incubated in anti-rabbit IgG secondary antibody conjugated with horseradish peroxidase (Boster Biological Technology, Ltd., Wuhan, China) 1:5,000 for $1 \mathrm{~h}$ at room temperature. Protein signal was detected using the SuperECL system (Nanjing KeyGen Biotech. Co., Ltd.) and detected by radiography. The immunoreactive bands were visualized using a Kodak 2000M camera (Eastman Kodak Co., Rochester, NY, USA) according to the manufacturer's instructions. An anti-GAPDH goat polyclonal antibody (1:500; Santa Cruz Biotechnology, Inc.) was used to confirm equal loading.

TSLP enzyme-linked immunosorbent assay (ELISA). TSLP in culture supernatants were detected by ELISA (R\&D Systems, 


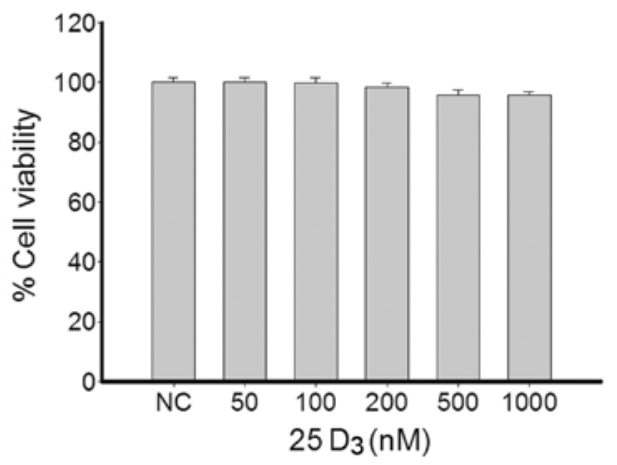

Figure 1. Effects of 25-hydroxyvitamin $\mathrm{D}_{3}\left(25 \mathrm{D}_{3}\right)$ on the viability of 16-HBE cells. 16-HBE cells were incubated with various concentrations of $25 \mathrm{D}_{3}$ (50-1,000 nM) for $24 \mathrm{~h}$. Cell viability was examined by MTT assay. Normal cell viability was set to $100 \%$. Each column represents the mean \pm SEM of triplicate respective determinations.

Minneapolis, MN, USA) according to the manufacturer's instructions and the data were normalized to the total protein amounts in the samples, as determined by Bradford assay (Bio-Rad, Hercules, CA, USA). The minimal detectable level of TSLP was $31.25 \mathrm{pg} / \mathrm{ml}$.

Statistical analysis. Data are presented as the means \pm SEM. Differences among multiple groups were assessed for statistical significance by one-way analysis of variance; Bonferroni's method was used for multiple comparisons. When 2 groups were being compared we used a one- or two-tailed Student's t-test depending on the hypothesis in question. A P-value $<0.05$ was considered to indicate a statistically significant difference.

\section{Results}

$25 \mathrm{D}_{3}$ induces TSLP expression in 16-HBE cells. A previous study demonstrated that respiratory epithelial cells have the enzymatic machinery required to activate vitamin $\mathrm{D}$, which exerts profound effects on epithelial cells (4). To determine whether inactive $25 \mathrm{D}_{3}$ affects TSLP expression in airway epithelial cells, we first investigated the effects of $25 \mathrm{D}_{3}$ on the viability of $16-\mathrm{HBE}$ cells. We found no loss in cell viability when the $16-\mathrm{HBE}$ cells were stimulated with various concentrations of $25 \mathrm{D}_{3}(50-1,000 \mathrm{nM}$ ) (Fig. 1). Based on our concentration-response curve, TSLP mRNA levels significantly increased at concentrations of $100 \mathrm{nM}$ and peaked at concentrations $500 \mathrm{nM} 25 \mathrm{D}_{3}$ (Fig. 2A). Therefore, we used the concentration of $500 \mathrm{nM}$ in the subsequent experiments. The time-response results revealed that TSLP mRNA (Fig. 2B) and protein (Fig. 2C) levels were significantly upregulated in the cells stimulated with $500 \mathrm{nM} 25 \mathrm{D}_{3}$ for 2 to $24 \mathrm{~h}$.

$25 \mathrm{D}_{3}$ induces VDUP1 expression in 16-HBE cells. To assess whether $25 \mathrm{D}_{3}$ induces VDUP1 expression in 16-HBE cells, we determined the mRNA and protein expression of VDUP1 following treatment with $25 \mathrm{D}_{3}$ from 0.5 to $24 \mathrm{~h}$. The results indicated that VDUP1 mRNA (Fig. 3A) and protein (Fig. 3B) expression was significantly upregulated in the 16-HBE cells treated with $500 \mathrm{nM} 25 \mathrm{D}_{3}$ for 2 to $24 \mathrm{~h}$ when compared with the untreated cells.
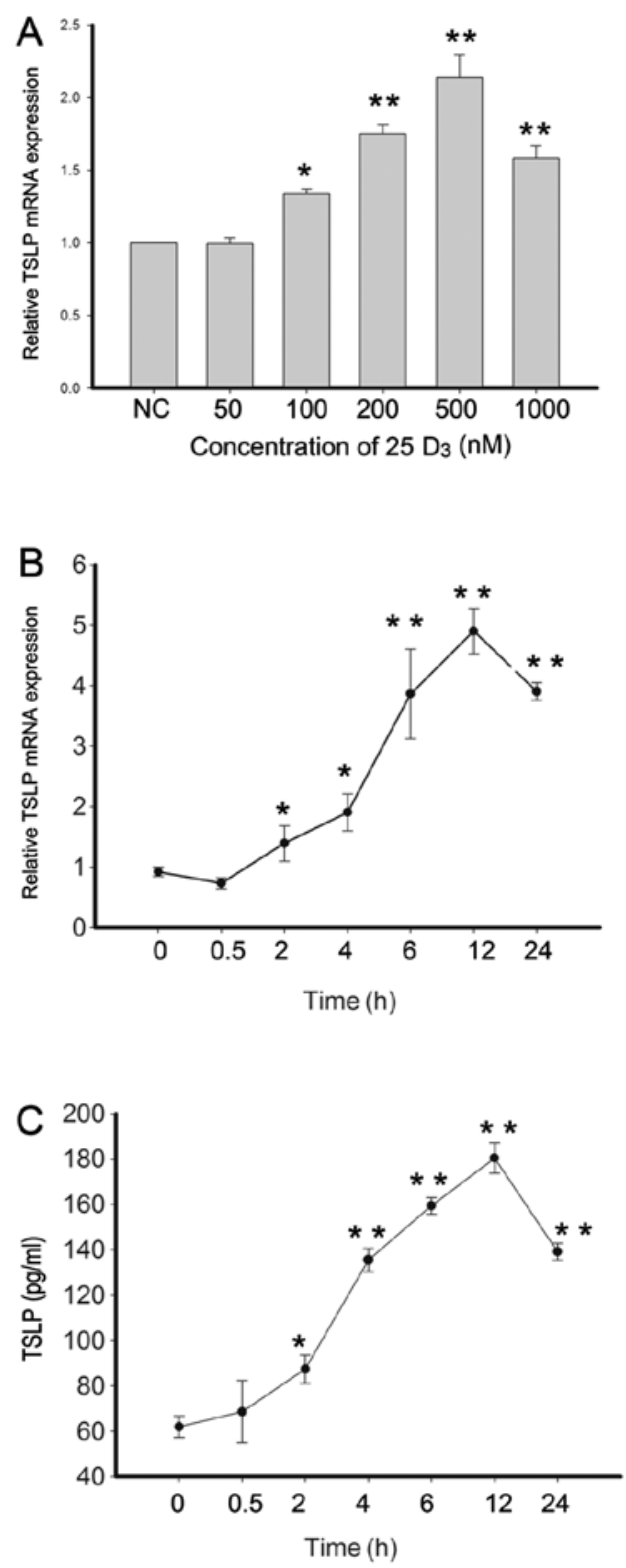

Figure 2.25-Hydroxyvitamin $\mathrm{D}_{3}\left(25 \mathrm{D}_{3}\right)$ induces thymic stromal lymphopoietin (TSLP) expression in 16-HBE cells. (A) TSLP mRNA levels in cells stimulated with different concentrations of $25 \mathrm{D}_{3}$ for $4 \mathrm{~h}$. (B) TSLP mRNA levels in cells stimulated with $500 \mathrm{nM} 25 \mathrm{D}_{3}$ for different periods of time. (C) TSLP protein levels in cells stimulated with $500 \mathrm{nM} 25 \mathrm{D}_{3}$ for different periods of time. Results are representative of 6 experiments $\left({ }^{*} \mathrm{P}<0.05,{ }^{* *} \mathrm{P}<0.01\right.$ vs. control).

VDUP1 silencing by RNAi. To determine the biological function of VDUP1, its expression was silenced by RNA interference. Three RNA duplexes (siRNA1, siRNA2 and siRNA3) directed against VDUP1 were synthesized (see Materials and methods). As shown in Fig. 4A and B, extracts prepared from the cells transfected with either the siRNA2 or siRNA3 duplex showed reduced VDUP1 levels. This effect was more pronounced with the use of siRNA3, wherein VDUP1 expression was $<35 \%$ of the control (Fig. 4B). siRNA1 and siRNA2 reduced VDUP1 expression to $40-80 \%$ of the control. Therefore, we selected VDUP1 siRNA3 in the subsequent experiments.

Silencing of VDUP1 decreases $25 D_{3}$-induced TSLP production in 16-HBE cells. To elucidate the mechanism behind the 


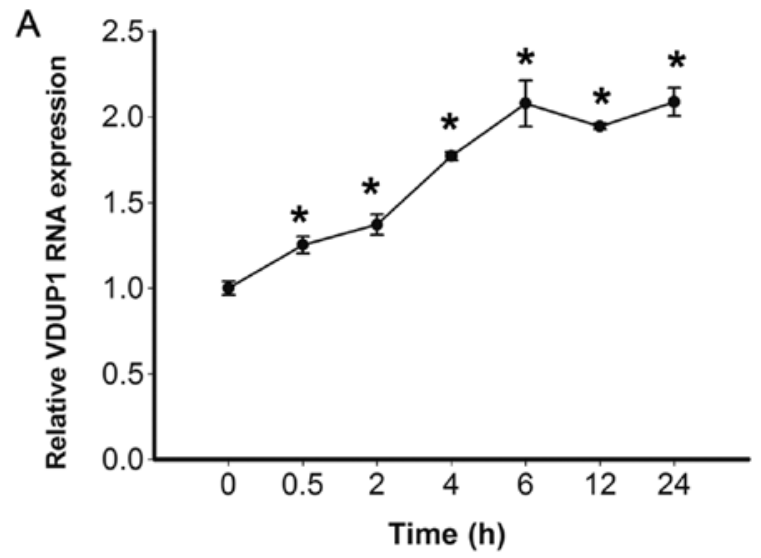

B

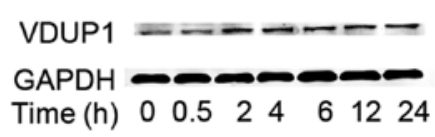

Figure 3. 25-Hydroxyvitamin $\mathrm{D}_{3}\left(25 \mathrm{D}_{3}\right)$ upregulates vitamin $\mathrm{D}_{3}$ upregulated protein 1 (VDUP1) expression in 16-HBE cells. (A) VDUP1 mRNA levels in cells stimulated with $500 \mathrm{nM} 25 \mathrm{D}_{3}$ for 0.5 to $24 \mathrm{~h}$. Results are a representative of 6 experiments $(* \mathrm{P}<0.05, \mathrm{n}=6)$. (B) Western blot analysis of VDUP1 expression in 16-HBE cells stimulated with $500 \mathrm{nM} 25 \mathrm{D}_{3}$ for 0.5 to $24 \mathrm{~h}$.
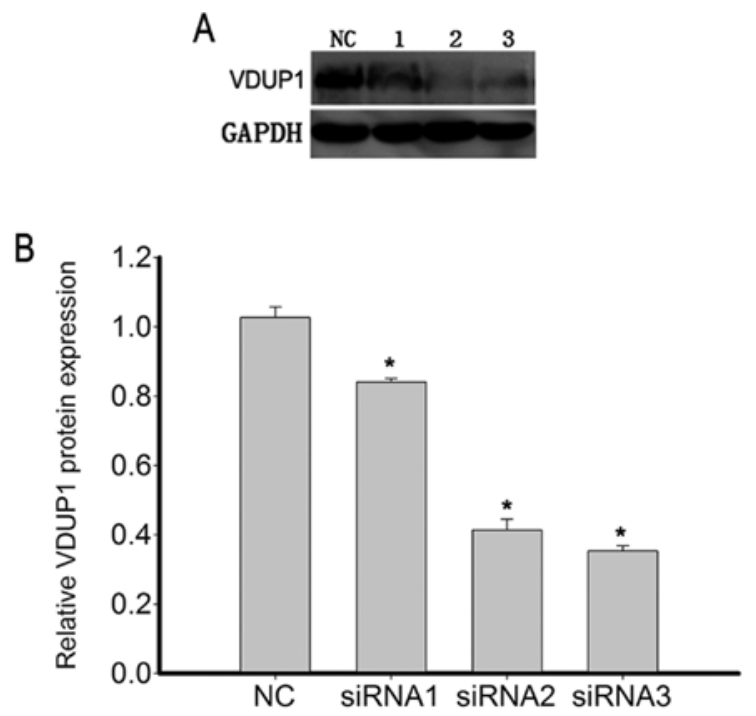

Figure 4. Vitamin $\mathrm{D}_{3}$ upregulated protein 1 (VDUP1) protein knockdown confirmed by western blot analysis. (A) Western blot analysis of VDUP1 expression in 16-HBE cells transfected with negative control (NC) or 3 VDUP1 small interfering RNAs (siRNAs). (B) Statistical plots of the western blot analysis results. ( $\mathrm{P}<0.05$ vs. $\mathrm{NC}, \mathrm{n}=5$ ). Lane 1 , VDUP1 siRNA1; lane 2, VDUP1 siRNA2; and lane 3, VDUP1 siRNA3.

$25 \mathrm{D}_{3}$-induced TSLP production, we investigated whether VDUP1 is involved in this process. We used VDUP1 siRNA3 to suppress VDUP1 expression in the 16-HBE cells. The viability of the cells was $>90 \%$ in the siRNA-transfected cells. We observed a significantly lower level of TSLP mRNA (Fig. 5A) and protein (Fig 5B) expression in the VDUP1silenced cells when compared with the control siRNA-treated cells following treatment with $500 \mathrm{nM} 25 \mathrm{D}_{3}$.
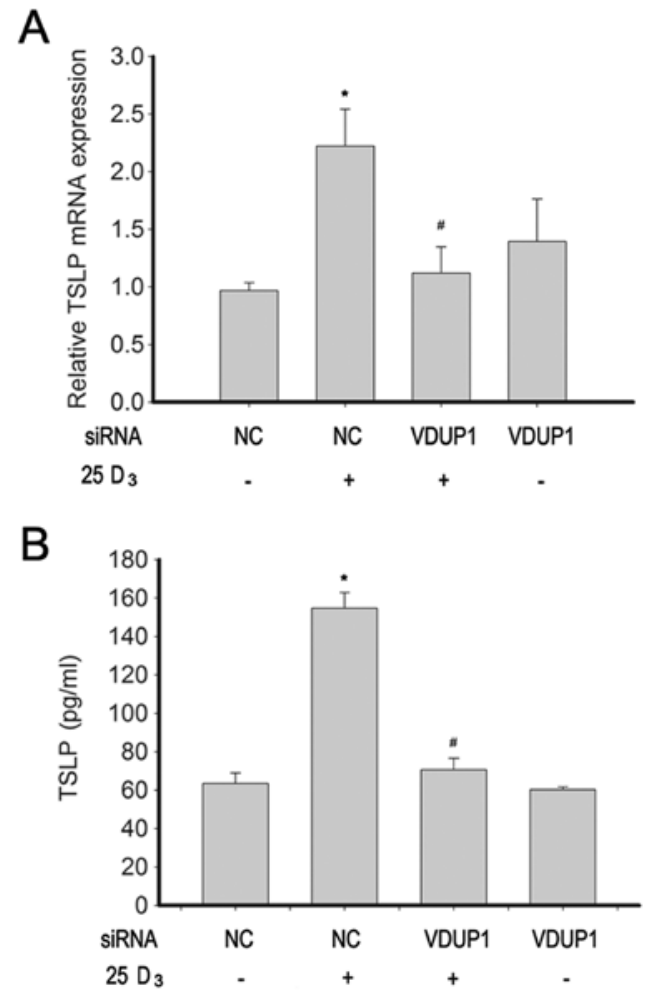

Figure 5. Silencing of vitamin $\mathrm{D}_{3}$ upregulated protein 1 (VDUP1) inhibits the 25-hydroxyvitamin $\mathrm{D}_{3}\left(25 \mathrm{D}_{3}\right)$-mediated induction of thymic stromal lymphopoietin (TSLP) in 16-HBE cells. (A) TSLP mRNA expression levels were analyzed by real-time RT-PCR in cells transfected with negative control (NC) or VDUP1 small interfering RNA (siRNA) and stimulated with $500 \mathrm{nM}$ $25 \mathrm{D}_{3}\left({ }^{*} \mathrm{P}<.005, \mathrm{n}=6\right)$. (B) The protein levels of secreted TSLP were analyzed by enzyme-linked immunosorbent assay (ELISA) in NC- or VDUP1 siRNAtransfected cells with or without stimulation with $500 \mathrm{nM} 25 \mathrm{D}_{3}$ ("P $<0.05$ vs. $\mathrm{NC},{ }^{\#} \mathrm{P}<0.05$ vs. $25 \mathrm{D}_{3}, \mathrm{n}=6$ ).

Inhibition of 1 $\alpha$-hydroxylase blocks the conversion of $25 D_{3}$ to $1,25 D_{3}$ and attenuates the upregulation of TSLP expression in 16-HBE cells. To determine the effect of $1,25 \mathrm{D}_{3}$, the 16-HBE cells were first treated with increasing concentrations of $25 \mathrm{D}_{3}$, and the levels of $1,25 \mathrm{D}_{3}$ in the supernatants were measured after $24 \mathrm{~h}$. Consistent with a previous study (4), our results indicated that the 16-HBE cells converted $25 \mathrm{D}_{3}$ to $1,25 \mathrm{D}_{3}$ when exposed to $25 \mathrm{D}_{3}$ without other stimuli (Fig. 6A). To further link the enzymatic machinery expressed by 16-HBE cells to the $1,25 \mathrm{D}_{3}$ generation and induction of TSLP expression, we used a chemical inhibitor of $1 \alpha$-hydroxylase, itraconazole. Pre-treatment of the 16-HBE cells with itraconazole $(1,000 \mathrm{nM})$ significantly reduced their ability to convert $25 \mathrm{D}_{3}$ to $1,25 \mathrm{D}_{3}$ (Fig. 6B). We then examined the effects of itraconazole on the induction of TSLP by $25 \mathrm{D}_{3}$. The results revealed that in the presence of itraconazole $(1,000 \mathrm{nM})$, there was a significantly lower production of TSLP mRNA (Fig. 6C) and protein (Fig. 6D) by $25 \mathrm{D}_{3}$. These results indicate that in the presence of itraconazole, less $25 \mathrm{D}_{3}$ is being converted to $1,25 \mathrm{D}_{3}$, resulting in a reduced production of TSLP.

VDUP1 silencing decreases 1,25 $D_{3}$-induced TSLP expression in 16-HBE cells. To further investigate the effect of active vitamin D on TSLP expression in airway epithelial cells, we directly used $1,25 D_{3}$ as the stimulator. We found no loss in cell 

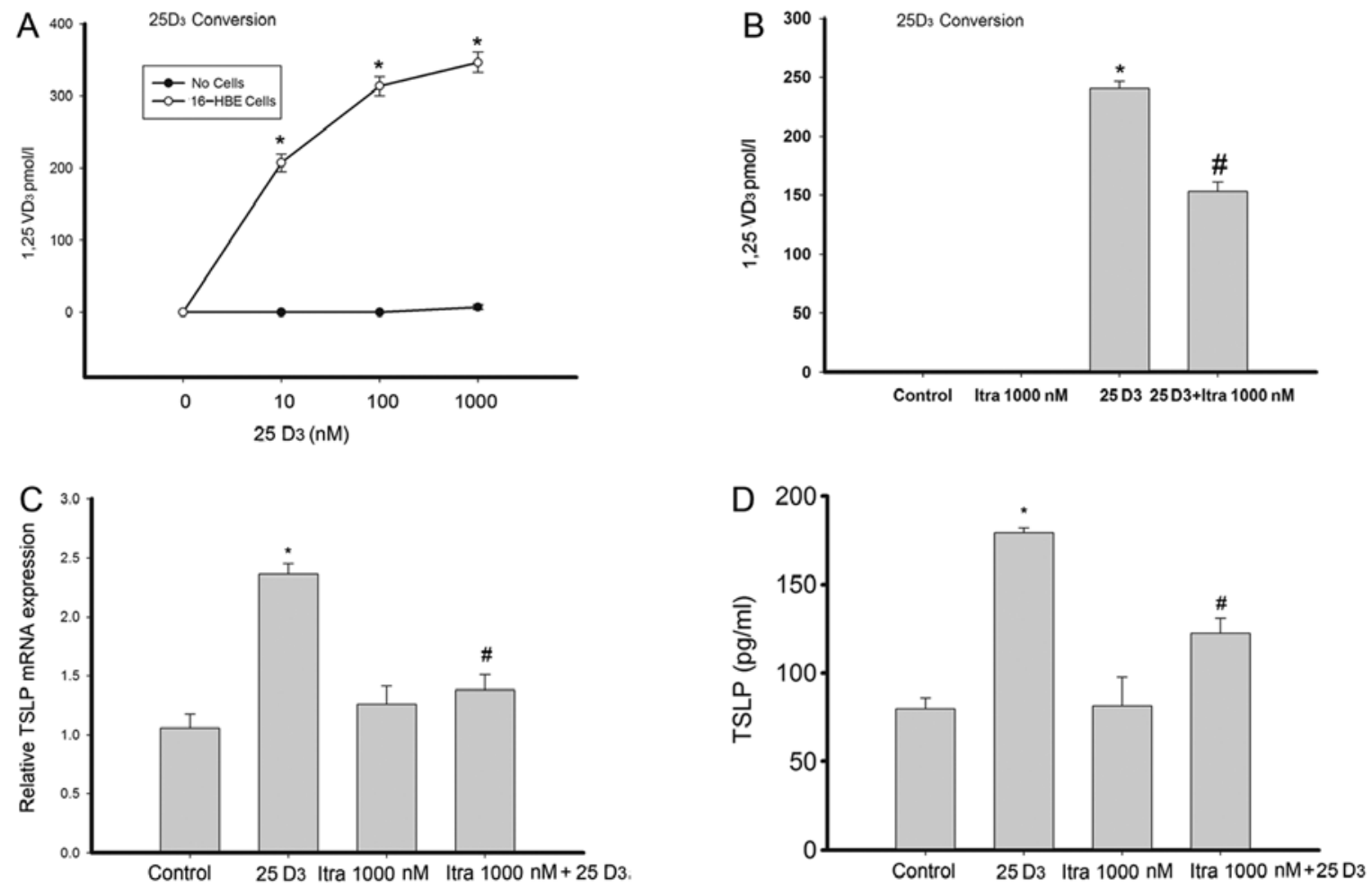

Figure 6. Inhibition of $1 \alpha$-hydroxylase reduces the conversion of 25-hydroxyvitamin $\mathrm{D}_{3}\left(25 \mathrm{D}_{3}\right)$ to 1,25 -dihydroxyvitamin $\mathrm{D}_{3}\left(1,25 \mathrm{D}_{3}\right)$ and attenuates the upregulation of stromal lymphopoietin (TSLP) expression in 16-HBE cells. (A) Cells were treated with increasing doses of $25 \mathrm{D}_{3}$ and $1,25 \mathrm{D}_{3}$ levels were measured in supernatants $24 \mathrm{~h}$ later. The 16-HBE cells converted inactive $25 \mathrm{D}_{3}$ to $1,25 \mathrm{D}_{3}$. The graph demonstrates the mean $1,25 \mathrm{D}_{3}$ levels and SEM of 3 or more independent experiments, as shown by the Student's t-test. (B) $1,25 \mathrm{D}_{3}$ levels were measured in the supernatants; pre-treatment of the 16-HBE cells with itraconazole $(1,000 \mathrm{nM})$ significantly reduced their ability to convert $25 \mathrm{D}_{3}$ to $1,25 \mathrm{D}_{3}$. The graph represents the mean $1,25 \mathrm{D}_{3}$ levels and SEM of 3 or more independent experiments. (C) TSLP mRNA level was analyzed by real-time RT-PCR (" $\mathrm{P}<0.05$ vs. control, ${ }^{\prime} \mathrm{P}<0.05$ vs. $25 \mathrm{D}_{3}$ ). (D) The protein levels of secreted TSLP stimulated with $500 \mathrm{nM} 25 \mathrm{D}_{3}$ with or without pre-treatment itraconazole (Itra) $(1,000 \mathrm{nM})$ were analyzed by enzyme-linked immunosorbent assay (ELISA) ("P<0.05 vs. control, ${ }^{*} \mathrm{P}<0.05$ vs. $25 \mathrm{D}_{3}$ ). Data shown are representative of 4 independent experiments with similar results.

viability when the $16-\mathrm{HBE}$ cells were stimulated with various concentrations of $1,25 \mathrm{D}_{3}(0.1$ to $100 \mathrm{nM})$ (Fig. $\left.7 \mathrm{~A}\right)$. Based on the concentration-response curve, TSLP mRNA (Fig. 7B) and protein (Fig. 7C) levels significantly increased at $0.1 \mathrm{nM}$, and peaked at concentrations of $50 \mathrm{nM} 1,25 \mathrm{D}_{3}$. The levels of TSLP mRNA (Fig. 7D) and protein (Fig. 7E) expression significantly increased at $2 \mathrm{~h}$ and peaked at $12 \mathrm{~h}$ in the cells exposed to $50 \mathrm{nM}$ $1,25 \mathrm{D}_{3}$. To determine the role of VDUP1 in this process, we examined the mRNA expression level of VDUP1 at the same time

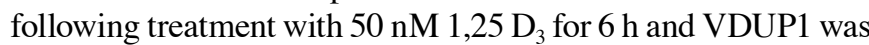
also manipulated via the siRNA-mediated silencing of VDUP1. The results revealed that VDUP1 mRNA (Fig. 7F) expression was significantly upregulated in the 16-HBE cells treated with

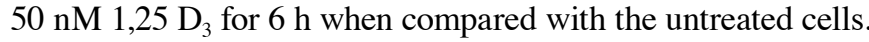
In comparison with the control siRNA-treated cells, following treatment with $50 \mathrm{nM} 1,25 \mathrm{D}_{3}$, we observed a significantly lower level of TSLP mRNA (Fig. 7G) and protein (Fig. 7H) in the cells in which VDUP1 was silenced. These results suggest that the VDUP1 pathway is involved in the 1,25 $\mathrm{D}_{3}$-induced TSLP expression in 16-HBE cells.

Inhibition of $1 \alpha$-hydroxylase exerts no effects on $1,25 D_{3}$-induced TSLP expression in 16-HBE cells. To confirm the specificity of the TSLP production induced by $1,25 \mathrm{D}_{3}$, we treated the cells with itraconazole, as well as $1,25 \mathrm{D}_{3}$. We found that in the presence of itraconazole $(1,000 \mathrm{nM})$, a similar induction of TSLP by
$1,25 \mathrm{D}_{3}$ was obsevered (Fig. 8A and B). This further supports our primary hypothesis that $1 \alpha$-hydroxylase converts inactive vitamin $\mathrm{D}$ to active vitamin $\mathrm{D}$ and induces TSLP expression in 16-HBE cells.

\section{Discussion}

In the present study, we investigated the effect of $25 \mathrm{D}_{3}$ and $1,25 \mathrm{D}_{3}$ on the expression of TSLP in 16-HBE cells and investigated the role of the VDUP1 pathway in this process. To the best of our knowledge, we are the first to demonstrate that: i) $25 \mathrm{D}_{3}$ and 1,25 $\mathrm{D}_{3}$ upregulate TSLP expression in 16-HBE cells; ii) the silencing of VDUP1 significantly inhibits the $25 \mathrm{D}_{3^{-}}$and 1,25 $\mathrm{D}_{3}$-mediated induction of TSLP expression; and iii) the inhibition of $1 \alpha$-hydroxylase by itraconazole partially suppresses the $25 \mathrm{D}_{3}$ - but not the $1,25 \mathrm{D}_{3}$-induced TSLP expression in 16-HBE cells.

In our study, we found that in comparison with $100 \mathrm{nM} 25 \mathrm{D}_{3}$, only $0.1 \mathrm{nM} 1,25 \mathrm{D}_{3}$ (normal range in the blood, 0.05-0.15 nM) significantly increased the expression of TSLP in airway epithelial cells. It should be noted that the stimulator concentrations of $25 \mathrm{D}_{3}$ at $500 \mathrm{nM}$ used in the assays in this study are considered supra-physiological (18). This concentration may have enhanced the direct effect of $1,25 \mathrm{D}_{3}$. Combined with the effects of the $1 \alpha$-hydroxylase inhibitor in our experiments, $25 \mathrm{D}_{3}$ was converted to $1,25 \mathrm{D}_{3}$, resulting in the induction of TSLP expres- 
A

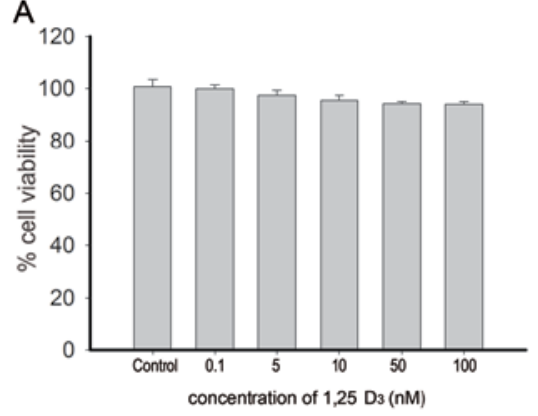

C

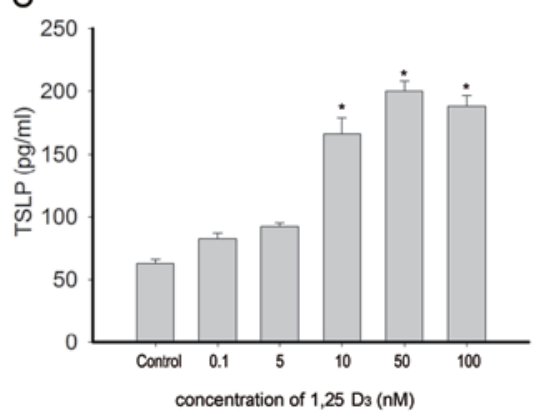

E

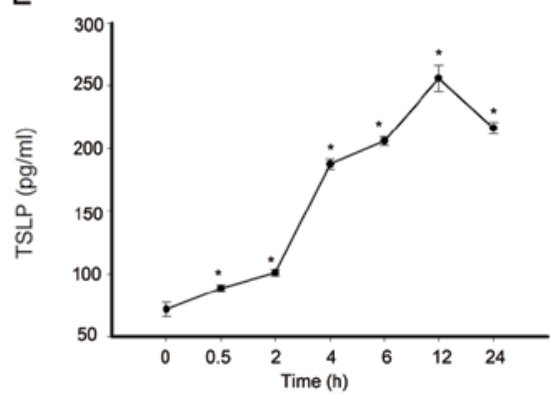

G

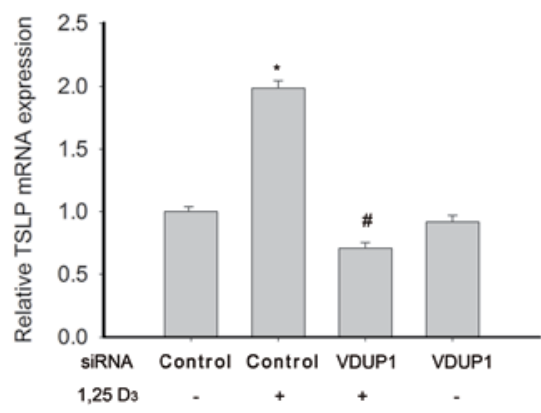

B

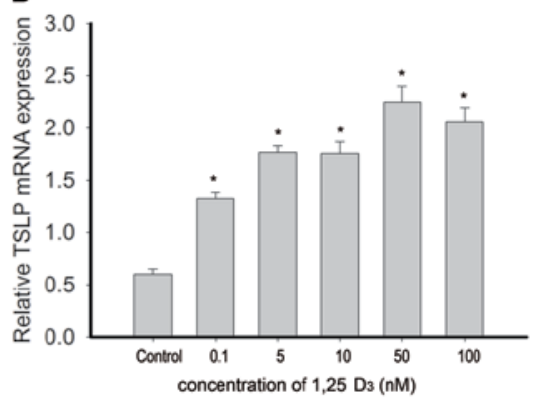

D

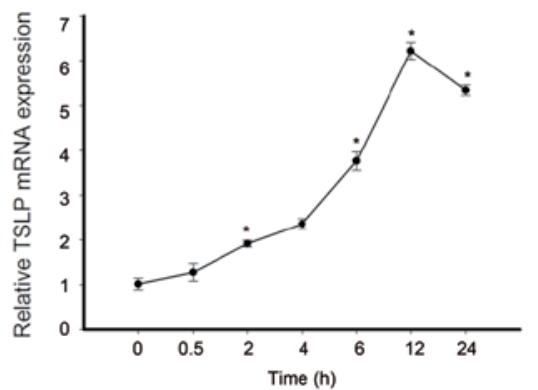

$\mathrm{F}$

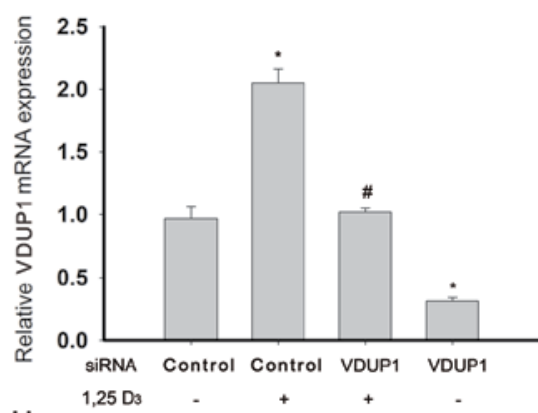

$\mathrm{H}$

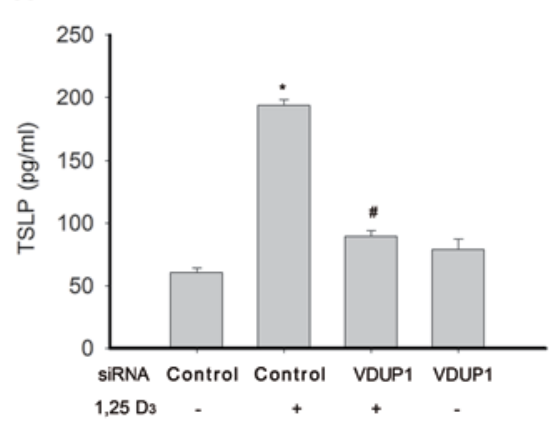

Figure 7. Vitamin $\mathrm{D}_{3}$ upregulated protein 1 (VDUP1) silencing also decreases the 1,25-dihydroxyvitamin $\mathrm{D}_{3}\left(1,25 \mathrm{D}_{3}\right)$-induced thymic stromal lymphopoietin (TSLP) expression in 16-HBE cells. (A) Cell viability of the cells stimulated with various concentrations of $1,25 \mathrm{D}_{3}(0.1-200 \mathrm{nM})$ was examined by MTT assay. Normal cell viability was set to $100 \%$. Each column represents the mean \pm SEM of triplicate respective determinations. (B) TSLP mRNA levels in cells stimulated with various concentrations of $1,25 \mathrm{D}_{3}(0.1-200 \mathrm{nM})$ for $4 \mathrm{~h}$. (C) TSLP protein levels in cells stimulated with various concentrations of $1,25 \mathrm{D}_{3}$

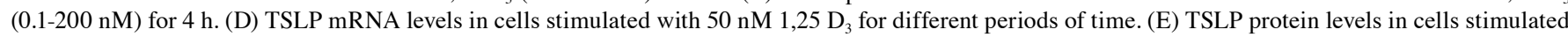

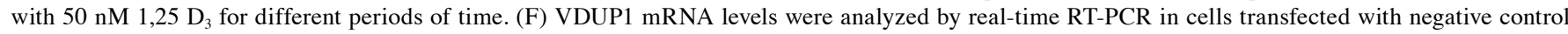
(NC) or VDUP1 small interfering RNA (siRNA) and stimulated with $1,25 \mathrm{D}_{3}\left({ }^{*} \mathrm{P}<0.05\right.$ vs. control, ${ }^{*} \mathrm{P}<0.05$ vs. $\left.1,25 \mathrm{D}_{3}\right)$. (G) Silencing of VDUP1 inhibited the $1,25 \mathrm{D}_{3}$-mediated induction of TSLP mRNA expression. (H) Silencing of VDUP1 inhibited the $1,25 \mathrm{D}_{3}$-mediated induction of TSLP protein expression. Results are representative of 5 experiments ( $\mathrm{P}<0.05$ vs. control, ${ }^{\#} \mathrm{P}<0.05$ vs. $1,25 \mathrm{D}_{3}$ ).

sion in 16-HBE cells. The physiological relevance of these findings is also limited by the use of $25 \mathrm{D}_{3}$ at the concentration of $500 \mathrm{nM}$. In this study, we observed that the peak of induction of TSLP expression occurred at 6 to $12 \mathrm{~h}$, which indicates that the effect of vitamin D on TSLP gene expression may be an indirect effect, which needs to be further clarified.

Usually, $25 \mathrm{D}_{3}$ is present at $\sim 1,000$-fold higher levels in the blood compared to $1,25 \mathrm{D}_{3}$, and the low level of $1,25 \mathrm{D}_{3}$ 

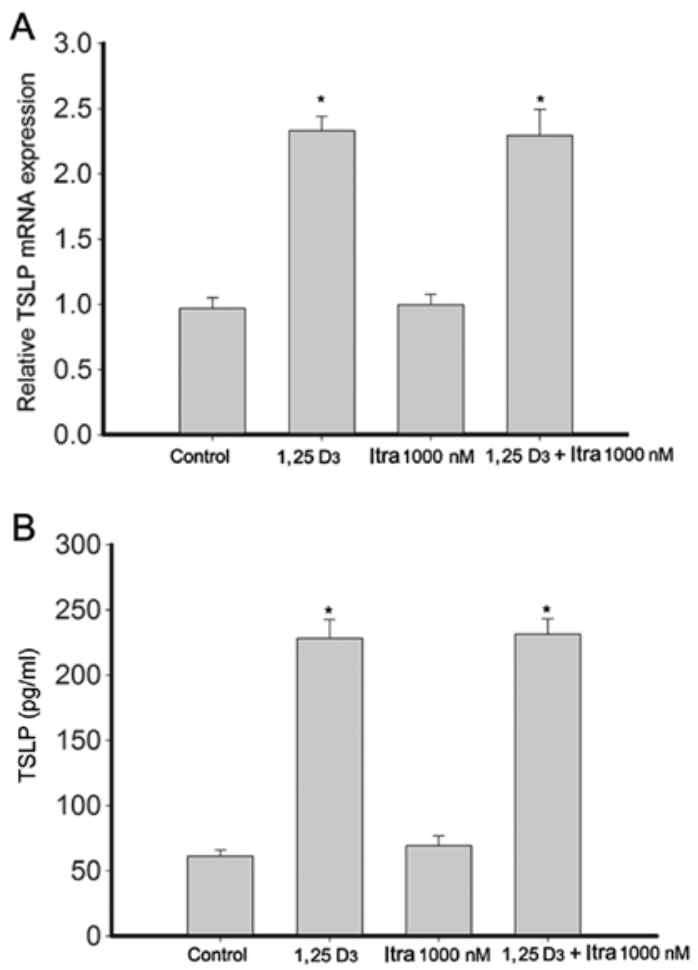

Figure 8 . Inhibition of $1 \alpha$-hydroxylase exerts no effects on 1,25-dihydroxyvitamin $\mathrm{D}_{3}\left(1,25 \mathrm{D}_{3}\right)$-induced thymic stromal lymphopoietin (TSLP) expression in 16-HBE cells. (A) TSLP mRNA levels in the cells stimulated with $50 \mathrm{nM}$ $1,25 \mathrm{D}_{3}$ with or without pre-treatment with itraconazole (Itra) $(1,000 \mathrm{nM})$ was analyzed by real-time RT-PCR ("P<0.05 vs. control). (B) The protein levels of secreted TSLP in cells stimulated with $50 \mathrm{nM} 1,25 \mathrm{D}_{3}$ with or without pre-treatment with itraconazole (Itra) $(1,000 \mathrm{nM})$ were analyzed by enzymelinked immunosorbent assay (ELISA) $\left({ }^{*} \mathrm{P}<0.05\right.$ vs. control). Data shown are representative of 5 independent experiments with similar results, as shown by the Student's t-test.

circulating systemically is likely insufficient to promote optimal immunoregulatory effects in vivo (18). Moreover, the commonly used concentration of $1,25 \mathrm{D}_{3}$ in vivo and in vitro that promotes optimal $1,25 \mathrm{D}_{3}$-dependent effects in several cell types, ranges from 10 to $100 \mathrm{nM}(4,19,20)$. In the concentration-response curve of $1,25 \mathrm{D}_{3}$, we observed that the induction of TSLP expression by $1,25 \mathrm{D}_{3}$ peaked at the concentration of 10-100 nM. Therefore, our data indicate that the airway epithelial cell production of active $1,25 \mathrm{D}_{3}$ from its inactive precursor is likely to be a crucial factor in the contribution of vitamin $\mathrm{D}$ to immune regulation in vivo.

Recently, emerging evidence suggests that vitamin D exerts a protective effect against asthma $(2,21,22)$. Other studies $(6,7,23)$ have indicated that TSLP represents a master switch of allergic inflammation and have established a direct link between TSLP expression in keratinocytes and airway epithelial cells and the pathogenesis of atopic dermatitis and asthma, respectively. It seems that our results contradict those from the abovementioned studies; in fact, the correlation between vitamin $\mathrm{D}$ and asthma has been a matter of debate for several years (24-26). A possible direct involvement of vitamin $\mathrm{D}$ signaling in atopy is supported by the observation that vitamin D receptor-null mutant mice fail to develop symptoms of experimental asthma. Li et al demonstrated that the topical induction of TSLP expression by $1,25 \mathrm{D}_{3}$ in mouse epidermal keratinocytes resulted in an atopic dermatitis-like syndrome (9). On the other hand, in combination with the previously known pro-T helper type 2 cytokine function, certain studies have indicated that TSLP plays a role in host defense $(27,28)$. Therefore, it is of interest to elucidate the role of the vitamin D-mediated production of TSLP in airway epithelial cells in asthma.

TSLP has been shown to be produced by airway epithelial cells $(6,29,30)$. However, the definite regulation of TSLP expression needs to be further clarified. TSLP expression has previously been shown to be regulated via the NF- $\mathrm{B}$ signaling pathway in airway epithelial cells $(30,31)$. Tumor necrosis factor- $\alpha$ and interleukin-1 $\beta$-induced TSLP expression has been shown to be regulated via the mitogen-activated protein kinase pathway in human airway smooth muscle cells (32). Our data demonstrated that the silencing of VDUP1 resulted in a significant reduction in $25 \mathrm{D}_{3}$ and $1,25 \mathrm{D}_{3}$-induced TSLP expression. These data suggest a novel pathway of TSLP regulation in airway epithelial cells.

However, the mechanism underlying the VDUP1-mediated upregulation of TSLP expression in 16-HBE cells remains unclear. VDUP1 interacts with the antioxidant, thioredoxin, thereby inhibiting the reducing activity of thioredoxin and blocking the interactions of thioredoxin with other factors, such as apoptosis signal-regulating kinase (12). This increases the vulnerability of cells to oxidative stress. In another study, Tang et al reported that reactive oxygen species mediate the release of TSLP by epithelial cells (33). Thus, the possible underlying mechanism is that VDUP1 promotes oxidative stress, which induces TSLP secretion followed by an increase in reactive oxygen species production through the inhibition of thioredoxin activity.

Of note, previous studies have demonstrated that: i) vitamin $D$ decreases the respiratory syncytial virus-mediated induction of the NF- $\mathrm{B}$-linked cytokine, interferon- $\beta$, and chemokine (C-X-C motif) ligand 10 in airway epithelial cells (34); and ii) Geldmeyer-Hilt et al demonstrated that $1,25 \mathrm{D}_{3}$ impairs NF- $\mathrm{B}$ activation in human naïve B cells (35). VDUP1 has been shown to suppress tumor necrosis factor- $\alpha$-induced $\mathrm{NF}-\kappa \mathrm{B}$ activation in hepatocarcinogenesis (15). Therefore the correlation between vitamin D, VDUP1, NF- $\kappa \mathrm{B}$ and TSLP under different circumstances requires further investigation.

There were obvious limitations to this study. First, although our data convincingly demonstrate that vitamin D metabolites increase TSLP expression, the biological consequences of such a regulation were not investigated. Second, the physiological relevance of our experiments was limited by the use of a transformed cell line; the results cannot necessarily be extrapolated to primary cells. Third, itraconazole is a broad spectrum inhibitor of cytochrome P450 enzymes, with activity against CYP24A as well as CYP27B1. The knockdown of CYP27B1 would provide more conclusive evidence that the pathway demonstrated was CYP27B1-dependent.

In conclusion, our data indicate that both inactive $25 \mathrm{D}_{3}$ and active $1,25 \mathrm{D}_{3}$ induce TSLP expression in 16-HBE cells, and that VDUP1-associated cell signaling is involved in this process. Further studies are required to determine the role of vitamin $\mathrm{D}$ and the mechanisms by which it modulates epithelial TSLP expression in airway diseases. 


\section{Acknowledgements}

This study was supported by grants from the National Natural Science Foundation of China (nos. 30971328, 81270087, 81270089); and the National Program on Key Basic Research Project (973 Program, 2012CB518203).

\section{References}

1. Pfeffer PE and Hawrylowicz CM: Vitamin D and lung disease. Thorax 67: 1018-1020, 2012.

2. Brehm JM, Acosta-Pérez E, Klei L, Roeder K, Barmada M, Boutaoui N, Forno E, Kelly R, Paul K, Sylvia J, Litonjua AA Cabana M, Alvarez M, Colón-Semidey A, Canino G and Celedon C: Vitamin D insufficiency and severe asthma exacerbations in Puerto Rican children. Am J Respir Crit Care Med 186: 140-146, 2012.

3. Boonstra A, Barrat FJ, Crain C, Heath VL, Savelkoul HF and O'Garra A: 1alpha,25-Dihydroxyvitamin D3 has a direct effect on naive CD4(+) T cells to enhance the development of Th2 cells. J Immunol 167: 4974-4980, 2001.

4. Hansdottir S, Monick MM, Hinde SL, Lovan N, Look DC and Hunninghake GW: Respiratory epithelial cells convert inactive vitamin $\mathrm{D}$ to its active form: potential effects on host defense. J Immunol 181: 7090-7099, 2008.

5. Zehnder D, Bland R, Walker EA, Bradwell AR, Howie AJ, Hewison $M$ and Stewart PM: Expression of 25-hydroxyvitamin D3-1alpha-hydroxylase in the human kidney. J Am Soc Nephrol 10: 2465-2473, 1999.

6. Soumelis V, Reche PA, Kanzler H, Yuan W, Edward G, Homey B, Gilliet M, Ho S, Antonenko S, Lauerma A, Smith K, Gorman D, Zurawski S, Abrams J, Menon S, McClanahan T, de Waal-Malefyt Rd R, Bazan F, Kastelein RA and Liu YJ: Human epithelial cells trigger dendritic cell mediated allergic inflammation by producing TSLP. Nat Immunol 3: 673-680, 2002.

7. Zhou B, Comeau MR, De Smedt T, Liggitt HD, Dahl ME, Lewis DB, Gyarmati D, Aye T, Campbell DJ and Ziegler SF: Thymic stromal lymphopoietin as a key initiator of allergic airway inflammation in mice. Nat Immunol 6: 1047-1053, 2005.

8. Wang TT, Tavera-Mendoza LE, Laperriere D, Libby E, MacLeod NB, Nagai Y, Bourdeau V, Konstorum A, Lallemant B Zhang R, Mader S and White JH: Large-scale in silico and microarray-based identification of direct 1,25-dihydroxyvitamin D3 target genes. Mol Endocrinol 19: 2685-2695, 2005.

9. Li M, Hener P, Zhang Z, Kato S, Metzger D and Chambon P: Topical vitamin D3 and low-calcemic analogs induce thymic stromal lymphopoietin in mouse keratinocytes and trigger an atopic dermatitis. Proc Natl Acad Sci USA 103: 11736-11741, 2006.

10. Chen KS and DeLuca HF: Isolation and characterization of a novel cDNA from HL-60 cells treated with 1,25-dihydroxyvitamin D-3. Biochim Biophys Acta 1219: 26-32, 1994.

11. Kim SY, Suh HW, Chung JW, Yoon SR and Choi I: Diverse functions of VDUP1 in cell proliferation, differentiation, and diseases. Cell Mol Immunol 4: 345-351, 2007.

12. Junn E, Han SH, Im JY, Yang Y, Cho EW, Um HD, Kim DK, Lee KW, Han PL, Rhee SG and Choi I: Vitamin D3 up-regulated protein 1 mediates oxidative stress via suppressing the thioredoxin function. J Immunol 164: 6287-6295, 2000.

13. Perrone L, Devi TS, Hosoya K, Terasaki T and Singh LP: Thioredoxin interacting protein (TXNIP) induces inflammation through chromatin modification in retinal capillary endothelial cells under diabetic conditions. J Cell Physiol 221: 262-272, 2009.

14. Zhou R, Tardivel A, Thorens B, Choi I. and Tschopp J: Thioredoxin-interacting protein links oxidative stress to inflammasome activation. Nat Immunol 11: 136-140, 2010

15. Kwon HJ, Won YS, Suh HW, Jeon JH, Shao Y, Yoon SR, Chung JW, Kim TD, Kim HM, Nam KH, Yoon WK, Kim DG, Kim JH, Kim YS, Kim DY, Kim HC and Choi I: Vitamin D3 upregulated protein 1 suppresses TNF-alpha-induced NF-kappaB activation in hepatocarcinogenesis. J Immunol 185: 3980-3989, 2010.

16. Cozens AL, Yezzi MJ, Kunzelmann K, Ohrui T, Chin L, Eng K, Finkbeiner WE, Widdicombe JH and Gruenert DC: CFTR expression and chloride secretion in polarized immortal human bronchial epithelial cells. Am J Respir Cell Mol Biol 10: 38-47, 1994.
17. Profita M, Bonanno A, Siena L, Ferraro M, Montalbano AM, Pompeo F, Riccobono L, Pieper MP and Gjomarkaj M: Acetylcholine mediates the release of IL-8 in human bronchial epithelial cells by a $\mathrm{NF \kappa B} / \mathrm{ERK}$-dependent mechanism. Eur J Pharmacol 582: 145-153, 2008.

18. Holick MF: Vitamin D deficiency. N Engl J Med 357: 266-281, 2007.

19. Campos LT, Brentani H, Roela RA, Katayama ML, Lima L, Rolim CF, Milani C, Folgueira MA and Brentani MM: Differences in transcriptional effects of 1alpha,25 dihydroxyvitamin D3 on fibroblasts associated to breast carcinomas and from paired normal breast tissues. J Steroid Biochem Mol Biol 133: 12-24, 2013.

20. Izban MG, Nowicki BJ and Nowicki S: 1,25-Dihydroxyvitamin D3 promotes a sustained LPS-induced NF-kappaB-dependent expression of CD55 in human monocytic THP-1 cells. PLoS One 7: e49318, 2012.

21. Wu AC, Tantisira K, Li L, Fuhlbrigge AL, Weiss ST and Litonjua A: Effect of vitamin D and inhaled corticosteroid treatment on lung function in children. Am J Respir Crit Care Med 186: 508-513, 2012.

22. Xystrakis E, Kusumakar S, Boswell S, Peek E, Urry Z, Richards DF, Adikibi T, Pridgeon C, Dallman M, Loke TK, Robinson DS, Barrat FJ, O'Garra A, Lavender P, Lee TH, Corrigan $\mathrm{C}$ and Hawrylowicz CM: Reversing the defective induction of IL-10-secreting regulatory $\mathrm{T}$ cells in glucocorticoid-resistant asthma patients. J Clin Invest 116: 146-155, 2006.

23. Leyva-Castillo JM, Hener P, Jiang H and Li M: TSLP produced by keratinocytes promotes allergen sensitization through skin and thereby triggers atopic march in mice. J Invest Dermatol 133: 154-163, 2012.

24. Back O, Blomquist HK, Hernell O and Stenberg B: Does vitamin $\mathrm{D}$ intake during infancy promote the development of atopic allergy? Acta Derm Venereol 89: 28-32, 2009.

25. Schauber J and Gallo RL: Vitamin D deficiency and asthma: not a strong link - yet. J Allergy Clin Immunol 121: 782-783; author reply 783-784, 2008.

26. Ginde AA and Sutherland ER: Vitamin D in asthma: panacea or true promise? J Allergy Clin Immunol 126: 59-60, 2010.

27. Sonesson A, Kasetty G, Olin AI, Malmsten M, Morgelin M, Sorensen OE and Schmidtchen A: Thymic stromal lymphopoietin exerts antimicrobial activities. Exp Dermatol 20: 1004-1010, 2011.

28. Kamekura R, Kojima T, Koizumi J, Ogasawara N, Kurose M, Go M, Harimaya A, Murata M, Tanaka S, Chiba H, Himi T and Sawada N: Thymic stromal lymphopoietin enhances tight-junction barrier function of human nasal epithelial cells. Cell Tissue Res 338: 283-293, 2009.

29. Allakhverdi Z, Comeau MR, Jessup HK, Yoon BR, Brewer A, Chartier S, Paquette N, Ziegler SF, Sarfati M and Delespesse G: Thymic stromal lymphopoietin is released by human epithelial cells in response to microbes, trauma, or inflammation and potently activates mast cells. J Exp Med 204: 253-258, 2007.

30. Kato A, Favoreto S Jr, Avila PC and Schleimer RP: TLR3and Th2 cytokine-dependent production of thymic stromal lymphopoietin in human airway epithelial cells. J Immunol 179: 1080-1087, 2007.

31. Lee HC and Ziegler SF: Inducible expression of the proallergic cytokine thymic stromal lymphopoietin in airway epithelial cells is controlled by NFkappaB. Proc Natl Acad Sci USA 104: 914-919, 2007.

32. Zhang K, Shan L, Rahman MS, Unruh H, Halayko AJ and Gounni AS: Constitutive and inducible thymic stromal lymphopoietin expression in human airway smooth muscle cells: role in chronic obstructive pulmonary disease. Am J Physiol Lung Cell Mol Physiol 293: L375-L382, 2007.

33. Tang H, Cao W, Kasturi SP, Ravindran R, Nakaya HI, Kundu K, Murthy N, Kepler TB, Malissen B and Pulendran B: The T helper type 2 response to cysteine proteases requires dendritic cell-basophil cooperation via ROS-mediated signaling. Nat Immunol 11: 608-617, 2010.

34. Hansdottir S, Monick MM, Lovan N, Powers L, Gerke A and Hunninghake GW: Vitamin D decreases respiratory syncytial virus induction of NF-kappaB-linked chemokines and cytokines in airway epithelium while maintaining the antiviral state. J Immunol 184: 965-974, 2010.

35. Geldmeyer-Hilt K, Heine G, Hartmann B, Baumgrass R, Radbruch A and Worm M: 1,25-dihydroxyvitamin D(3) impairs NF-kappaB activation in human naive B cells. Biochem Biophys Res Commun 407: 699-702, 2011. 